\title{
Socio-psychological impact on Bangladeshi students during COVID-19
}

\author{
Syed Far Abid Hossain, ${ }^{1}$ Mohammad Nurunnabi, ${ }^{2}$ Sheela Sundarasen, ${ }^{2}$ Karuthan Chinna, ${ }^{3}$ \\ Kamilah Kamaludin, ${ }^{2}$ Gul Muhammad Baloch, ${ }^{3}$ Heba Bakr Khoshaim, ${ }^{4}$ Areej Sukayt ${ }^{2}$ \\ ${ }^{1}$ College of Business Administration, International University of Business Agriculture and Technology (IUBAT), \\ Uttara Model Town, Dhaka, Bangladesh; ${ }^{2}$ Department of Accounting, Prince Sultan University, Riyadh, Saudi \\ Arabia; ${ }^{3}$ Faculty of Health and Medical Sciences, School of Medicine, Taylor's University, Subang Jaya, \\ Selangor, Malaysia; ${ }^{4}$ Deanship of Educational Services, Prince Sultan University, Riyadh, Saudi Arabia
}

\begin{abstract}
Background: The socio-psychological impact of COVID-19 has affected the whole world. Bangladesh, one of the most dangerous places as stated by WHO, was first infected at the beginning of March 2020, later than other countries. Bangladesh is now one of the 20 most affected countries in the world, but the psychological effects for university students during the epidemic period are not researched.

Design and methods: To address this gap, the present study attempts to discover the socio-psychological impact of COVID-19 on university students in Bangladesh. We conducted an online survey using a questionnaire with a simple random sampling technique and we received 474 responses.

Results: In this study, numerous psychological concerns were reported. The study is limited to university students, which may affect the generalizability of the research.

Conclusions: Our findings suggest a need to build awareness of the mental health implications of the pandemic for university students.
\end{abstract}

\section{Introduction}

Bangladesh is one of the 20 most affected countries in the world and 57,563 confirmed COVID-19 cases and 781 deaths following the first COVID-19 case on March $8^{\text {th }} 2020 .{ }^{1}$ On March $23^{\text {rd }}$, the legislature proclaimed a common leave from March $26^{\text {th }}$ to May $30^{\text {th }}$, prompting the closure of administration offices, nongovernment workplaces, and law offices, and shorter working hours for business banks. On April $8^{\text {th }}$, the government restricted activities $^{1}$ in sites for displaced Rohingya to basic managements and assistance, referring to the need to limit any chance of infection at the site. With the first cases in the camps confirmed toward the end of May, health authorities are now worried about the outcome of a flare-up, as the clinical services for displaced people are poor. Our World in $\mathrm{Data}^{2}$ and European $\mathrm{CDC}^{3}$ represent the increasing confirmed death rate in Bangladesh. However, despite this increase, on May $28^{\text {th }}$ the specialists declared that terminations and development limitations would be gradually lifted from May $31^{\text {st }}$. Apart from the impact on households of the health emergency, the two primary areas of the Bangladeshi budget that will be affected are settlements and Ready-Made Garments (RMG). Settlements account more than $5 \%$ of GDP ( $\$ 16.4$ billion in FY 19), and most transient laborers are situated in Gulf nations, which are influenced by the unexpected fall in oil prices. The RMG element represents in excess of $80 \%$ of the nation's fares. ${ }^{1}$ Business has been hit by losses of a few billion US dollars caused by the cancellation or delay in orders from significant retailers overseas, although top worldwide clothing brands reported on April $1^{\text {st }}$ that they would take shipments of products previously created. The Bangladesh Garment Manufacturers and Exporters Association have taken steps to boycott retailers with extraordinary installments for suspended requests. Although this does not directly affect students, tuition fees and other academic costs are usually provided by their parents or guardians, who may be affected badly by the COVID-19 issue. Furthermore, managements around the globe have provisionally locked learning organizations in an effort to control the spread of the virus. Across the nation, closures have affected over $60 \%{ }^{1}$ of the world's student population. A few countries have executed partial closures, distressing a large number of students. UNESCO is supportive to states trying to alleviate the abrupt effect of school closures, especially for progressively defenseless and impeded networks, and encourage the coherence of tutoring for all through distant education. Throughout the world, COVID-19 has been extensively investigated in various areas; however, the socio-psychological impact from the students' perspective in Bangladesh has not been investigated so far to ensure sustainable educational development. Compared to other countries, Bangladesh is different in terms of massive population. In addition, Bangladesh is a very small country with less GDP compared to other developing and developed countries in the world. That is why it's crucial to investigate the socio-psychological impact on Bangladeshi students during COVID-19.

Significance for public health

Due to COVID-19, the world is facing innumerable difficulties. However, the most crucial difficulty is the socio-psychological pressure on university students. Considering the risk of infection, the university authority and policy-makers adopted secure lockdown and control measures. Although the classes conducted online in many educational institutions, the lack of necessary technological and financial support is a key concern for developing countries such as Bangladesh. This phenomenon is a reason of public health concern in terms of anxiety and coping. Socio-psychological impact is severe but complicated to measure and control. As a result, this could be a threat for ensuring sustainable public health in the society. This research is an attempt to shed lights on ensuring harmony and secure mental health and well-being among the university students during COVID-19. 


\section{Literature review}

Bangladesh is one of the developing countries in Asia with an increased poverty rate and slum-dwelling populations. ${ }^{4}$ The country is tiny for its large population size. Dhaka city, the capital of Bangladesh, is one of the most polluted cities in the world with a high population density. As COVID-19 is highly infectious, the socio-psychological impact is severe. In addition, average GDP is very low compared to developed countries. Some people live from hand to mouth. Many of them are daily laborers with no savings at all. As a result, they are vulnerable to the socio-psychological effects of COVID-19. Recent research presented a suicide case in Bangladesh due to socio-psychological pressure in Bangladesh. ${ }^{5}$ Fear of COVID-19 is the most influential cause resulting from the psychological pressure on everyone. ${ }^{6}$ Many illiterate people still believe that COVID-19 is a curse from God and is unavoidable. Also, some local people blame infected people and avoid giving any kind of help or assistance. People are observed to receive an unusual funeral after their death due to the COVID-19 infection fear. Every society has its own culture, beliefs and psychological background, including Bangladesh; however, the country is more vulnerable to an adverse socio-psychological impact to its society. ${ }^{7}$ This kind of impact is even more acute for students, especially mature students with more self-respect.

Bangladesh is one of the countries that tried non-therapeutic preventive measures ${ }^{8}$ during COVID-19 as many people did not want to visit the hospital for testing due to fear and socio-psychological pressure. Job losses and lower recruitment rates have also affected many people in Bangladesh at the same time. ${ }^{9}$ As a result, the students, especially final-year students, have felt mental pressure because of limited recruitment potential in the job market. Although lockdown is strictly maintained in Bangladesh, ${ }^{10}$ students were observed to express their wish to return to their regular campus.

In many countries, students are learning online with various apps and online learning platforms with the advanced technology of m-learning. ${ }^{11}$ However, in Bangladesh, there are many people without the technological facilities to do so. The socio-psychological impact of not being able to access a device for attending online classes is very pathetic for the students in financial difficulty. In order to cope with the current trend, students need to acquire at least a mobile device such as a laptop or tablet or a high quality smartphone in order to attend lectures online on various platforms such as Zoom, ClassIn, and BIDMA. However, devices are not the only solution. In order to ensure smooth online classes, an uninterrupted network is also necessary with a strong Wi-Fi connection, which is still not available in many rural areas of Bangladesh. As a result, the psychological impacts on students demotivate them to continue study during COVID-19.

Uncertainty is a major socio-psychological concern in Bangladesh due to COVID-19. COVID-19 affects each country differently and different countries adopt different coping strategies to tackle the situation. However, people are not mentally strong ${ }^{12}$ everywhere, especially in a developing country like Bangladesh where people usually don't have sufficient savings to survive a lengthy lockdown period. The mental health of schoolchildren has also been investigated recently, which is even more unusual due to social distance. Little kids are controllable with various indoor activities; however, the socio-psychological tendency is that university students are difficult to manage as they are adult, and they have their own sense and judgment. Students' attitude to m-learning ${ }^{11}$ has been investigated recently; however, there is no connec- tion with m-learning in special pandemic situation such as COVID-19. A decision of the university authorities and government could make significant changes in this regard; however, as Bangladesh has been declared a high-risk country by WHO, ${ }^{13}$ its universities still depend on a decision by central government. ${ }^{14}$ Due to this delay, students are mentally depressed and demotivated. ${ }^{14}$ Commuting ${ }^{15}$ is another big issue in this regard. Many students study in the capital city but they are now staying in their hometown with parents and relatives. With emergency commuting permission only, people are increasingly facing socio-psychological problems. ${ }^{16}$ Researchers have also investigated the sexual and reproductive health and rights under COVID-19 in Bangladesh, which also indicate severe socio-psychological effects among mass population. ${ }^{17}$ At the same time, in other countries such as China, the same socio-psychological issue is evident. ${ }^{18}$ It indicates that the problem is not only acute globally but also significant in specific countries such as Bangladesh, and research should focus on countries individually as risk management in China and Bangladesh could be completely different. ${ }^{19}$

\section{Design and Methods}

This was a person-administered survey, carried out in Bangladesh. A random sampling technique was used. An online semi-structured questionnaire was established using a Google form. The link for the questionnaire was sent to participants by various Social Networking Sites (SNSs), like Facebook and especially WhatsApp, as these SNSs are widely used in Bangladesh. The participants were encouraged to complete the survey by the offer of reward money. The link was forwarded to students in various academic and study groups where the group admin was responsible to ensure the distribution of prize money. On receiving and clicking the link the contributors were sent consent information. After giving consent, they completed up the demographic details requested on the form. Numerous questions appeared consecutively, which the participants had to answer in order to go to the next section. The survey was mainly based online due to the epidemic. Anyone with access to Internet could contribute to the study. Contributors over 18 years who were able to understand Chinese and could give informed consent were included. The data collection was initiated on May $23^{\text {rd }}, 2020$ at 10:23 am and closed on June $5^{\text {th }}, 2020$ at 16:51 pm. We were able to collect data from across various provinces of Bangladesh. For questionnaire development, Zung's ${ }^{20}$ Self-rating Anxiety Scale (SAS) was used in this study. The authors utilized the English version of Zung's SAS and later translated in local language. To maintain and ensure the accuracy, the authors re-translated the local version into English. The sociodemographic variables included age, gender, field of study, level of study, current accommodation and current stay (with whom). The online self-reported questionnaire developed by the investigators contained the following sections related to anxiety: "Demographic characteristics of the respondents," "Level of anxiety," "Coping strategies," and "Anxiety level with coping strategies." There were 20 multiple choice questions in the personal situation section, four multiple choice questions in the social appeal section, four multiple choice questions in the mental liberation section, and three multiple choice questions in the humanitarian section, all of which were to be rated "Never" to "Always"; and there were fifteen multiple choice questions in the health status section to be rated "Not applicable" to "More than ever." 


\section{Results}

In this study, a total of 495 responses were received. After data cleaning, 474 responses were found to be usable. The demographic characteristics of the respondents are diverse. Among the respondents, $38.2 \%$ were females and the majority (46\%) were in the $26-$ 32 age group. About $52.1 \%$ respondents were from the school of business and management. About $65.6 \%$ of the students in this study were masters' students and about $46.8 \%$ of them were in their first year of study. Most of the students (91.1\%) mentioned that their universities had started a virtual mode of delivery. For accommodation, $56.8 \%$ were living in their dormitory.

\section{Levels of anxiety among college students during the epidemic}

Zung's SAS ${ }^{20}$ includes 20 items, all scored on a scale from 1 to 4 . The scores for the 20 items are shown in the tables below as a summarized representation. For individual participants, the overall anxiety score was attained by totaling the responses for the 20 items. The entire score fluctuated from 20 to 80 . The scores were later changed to an "Anxiety Index" score with numbers from 25 to 100. According to Zung ${ }^{20}$ an Anxiety Index $<45$ specifies "Anxiety within normal range," a score in the range of 45-59 indicates "Mild to moderate anxiety" a score in the range of 60-74 specifies "marked to severe anxiety" and values $\geq 75$ indicate "Most extreme anxiety."

According to the survey conducted in this study, 192 (40.5\%), $13(2.47 \%)$ and $86(18.1 \%)$ reported "minimal to moderate," "marked to severe," and "most extreme" anxiety as presented in Table 2 below. For additional examination, the circumstances with marked to severe anxiety and most extreme anxiety were assembled together and named as "severe to extreme" of anxiety.

\section{Factors associated with college students' anxiety during the epidemic}

\section{Univariate analysis}

The results from chi-square analyses for the tests of association between students' demographic variables and anxiety are presented in Table 1. All the tested variables were significant. Hence all were tested in multivariate analysis.

\section{Ordinal regression analysis}

In multivariate analysis all the variables, except for the two variables on living arrangements, were significant (Table 2).

The odds of female students being more anxious were higher than for the male students $(\mathrm{OR}=1.618,95 \% \mathrm{CI}=1.064,2.460$, $\mathrm{p}=0.024$ ) and the odds of higher level of anxiety for Chinese students was higher than for Bangladeshi students $(\mathrm{OR}=2.200,95 \%$ $\mathrm{CI}=1.413,3.426, \mathrm{p}<0.001)$. The older students experienced more anxiety compared than below the age of 18 , with OR values ranging from 10.235 to 24.326 . Compared to students from other col- leges, students from Business/Management, Engineering and Social Science/Humanities experienced more anxiety (OR ranged from 2.502 to 2.971). Compared to $\mathrm{PhD}$ students, undergraduates $(\mathrm{OR}=17.671)$ and masters students $(\mathrm{OR}=2.532)$ were more anxious. For year of study, compared to those in their fifth year and above, those in the second $(\mathrm{OR}=10.148)$ and third years $(\mathrm{OR}=21.741)$ had more anxiety. Students who had to learn via virtual modes of delivery also showed high anxiety $(\mathrm{OR}=3.774,95 \%$ $\mathrm{CI}=1.808,7.874, \mathrm{p}<0.001)$. Table 3 below represents the result from stepwise ordinal multivariate analysis.

\section{Discussion}

The discussion in the study is drawn from the analysis where variation is observed among different groups of students (for example male and female students). Although all are students, they vary in psychological their aspects. For example: female students are more worried in terms of anxiety and older students experienced a higher rate of anxiety according to the statistical analysis discussed above. Pandemics, epidemics and market turbulence are unanticipated natural calamities that are inescapable. The sociopsychological effects are varied based on financial and technological differences. Although the world has experienced several-life threatening epidemics, socio-psychological and control measures play a key role in the community. Students, especially university students, are independent and focused on their studies and careers, which may be affected by outbreaks such as COVID-19. In addition, unpredictable outbreaks may seriously affect their academic achievements. ${ }^{21}$ A lack of regular and routine activities such as attending classes, meeting friends, visiting the library or the lab can psychologically affect students. ${ }^{14}$ The findings of the study indicate students' eating and drinking behavior was much as usual; however, the results also show a significant positive relationship between anxiety and academic issues such as on-time course completion. Most students had not faced this kind of outbreak before in Bangladesh and that is the reason they are psychologically more affected.

The findings of this study are consistent with the fact that lockdown strategies, proper healthcare facilities and safety measures are major concerns affecting socio-psychological issues in Bangladesh. They may adversely affect the community and society as a whole and the mental health of the population and students in particular. Because of psychological problems such as fear and anxiety, students may fail to achieve their expected academic result on time. Current research ${ }^{22}$ has conducted a parallel study based on Indian citizens. In that study the authors referred to frequent use and shortage of hand sanitizers, hand wash, and face masks. These measures indicate the cumulative concern of people about psychological measures to avoid COVID-19 infection. Every epidemic has its unique characteristics in terms of causality, risks and control measures. COVID-19 is no different; however, the socio-psycho-

Table 1. Anxiety level based on Zung's classification.

\begin{tabular}{lccccc} 
Anxiety & Frequency & Percentage & Anxiety & Frequency & Percentage \\
Normal & 183 & 38.6 & Normal & 183 & 38.6 \\
Minimal to moderate & 192 & 40.5 & Minimal to moderate & 192 & 40.5 \\
\hline Marked to severe & 13 & 2.7 & Severe to extreme & 99 & 20.9 \\
Most extreme & 86 & 18.1 & & & \\
\hline
\end{tabular}


logical pressure is acute in terms of measurement control in the community. Back in 2015, during the Ebola virus outbreak in Ethiopia, the coping measures and awareness were comparatively unsatisfactory. ${ }^{23}$

Among university students, socio-psychological issues are directly associated with anxiety levels. The highest anxiety level in this study is reported by $18.1 \%$ of students, which is almost onefifth of the total sample size. "Seeking social support," "avoidance," "mental disengagement," and "humanitarian issues" are tested as coping strategies in this study. For all the four cases the $\mathrm{p}$-value is $<0.001$, between the coping strategies and the anxiety level. This result indicates a strong positive relationship between coping strategies and the anxiety level of students. The contributors this study had a satisfactory level of awareness concerning COVID-19 and most of them took preventive measures. ${ }^{24}$ In
Bangladesh, the local government and community members emphasized such preventive measures as lockdown, temperature checks, wearing respiratory masks and so on.

The respondents in this study reported that most of their school and academic units relied on online teaching during the epidemic. A total of $91.1 \%$ reported that their academic institution conducted online lectures, training sessions, video conferencing, competitions, award ceremonies and so on; and $64.4 \%$ of respondents reported that in the second month of the outbreak, their academic institutions started online classes. Due to increased anxiety and uncertainty about the continuation of their studies, students reported more anxiety than usual (85.86\%). Similarly, sleeping problems and nightmares were also reported at a higher rate than before; and $36.91 \%$ of respondents reported getting no emotional support from their friends. This could be because of a higher number of students

Table 2. Results from univariate analysis.

\begin{tabular}{|c|c|c|c|c|c|}
\hline Variable & Normal (\%) & Minimal to moderate & Severe to extreme (\%) & Chi-square & p \\
\hline $\begin{array}{l}\text { Gender } \\
\quad \text { Female } \\
\text { Male }\end{array}$ & $\begin{array}{c}41(22.7) \\
142(48.5)\end{array}$ & $\begin{array}{c}82(45.3) \\
110(37.5)\end{array}$ & $\begin{array}{l}58(32.0) \\
41(14.0)\end{array}$ & 38.427 & $<0.001$ \\
\hline $\begin{array}{l}\text { Age } \\
\begin{array}{l}18 \text { and below } \\
19-25 \text { years } \\
26-32 \text { years } \\
33-40 \text { years } \\
\text { Above } 40 \text { years }\end{array}\end{array}$ & $\begin{array}{l}87(75.0) \\
22(58.6) \\
52(23.9) \\
12(33.3) \\
10(37.0)\end{array}$ & $\begin{array}{c}22(19.0) \\
17(22.1) \\
119(54.6) \\
19(52.8) \\
15(55.6)\end{array}$ & $\begin{array}{c}132.994 \\
7(6.0) \\
38(49.4) \\
47(21.6) \\
5(13.9) \\
2(7.4)\end{array}$ & $<0.001$ & \\
\hline $\begin{array}{l}\text { Nationality } \\
\text { Bangladeshi } \\
\text { Chinese } \\
\text { Pakistani }\end{array}$ & $\begin{array}{l}117(39.7) \\
56(34.1) \\
10(66.7)\end{array}$ & $\begin{array}{c}129(43.7) \\
59(36.0) \\
4(26.7)\end{array}$ & $\begin{array}{c}49(16.6) \\
49(29.9) \\
1(6.7)\end{array}$ & 16.669 & 0.002 \\
\hline $\begin{array}{l}\text { College } \\
\text { Business/Management } \\
\text { Engineering } \\
\text { Social Science/Humanities } \\
\text { Others }\end{array}$ & $\begin{array}{l}115(46.6) \\
34(30.6) \\
18(25.7) \\
16(34.8)\end{array}$ & $\begin{array}{l}91(36.8) \\
40(36.0) \\
33(47.1) \\
28(60.9)\end{array}$ & $\begin{array}{c}41(16.6) \\
37(33.3) \\
19(27.1) \\
2(4.3)\end{array}$ & 33.642 & $<0.001$ \\
\hline $\begin{array}{l}\text { Level of Study } \\
\text { Masters } \\
\text { PhD } \\
\text { Undergraduate }\end{array}$ & $\begin{array}{l}138(43.8) \\
22(41.5) \\
23(21.7)\end{array}$ & $\begin{array}{l}121(38.4) \\
21(39.6) \\
50(47.2)\end{array}$ & $\begin{array}{l}56(17.8) \\
10(18.9) \\
33(31.1)\end{array}$ & 18.575 & 0.001 \\
\hline $\begin{array}{l}\text { Year of study } \\
\text { Year } 1 \\
\text { Year } 2 \\
\text { Year } 3 \\
\text { Year } 4 \\
\text { Year } 5 \text { and above } \\
\end{array}$ & $\begin{array}{l}110(49.5) \\
20(22.2) \\
18(23.7) \\
16(35.6) \\
19(46.3)\end{array}$ & $\begin{array}{l}97(43.7) \\
29(32.2) \\
25(32.9) \\
21(46.7) \\
20(48.8)\end{array}$ & $\begin{array}{c}15(6.8) \\
41(45.6) \\
33(43.4) \\
8(17.8) \\
2(4.9)\end{array}$ & 93.715 & $<0.001$ \\
\hline $\begin{array}{l}\text { Virtual learning } \\
\text { Yes } \\
\text { No }\end{array}$ & $\begin{array}{c}159(36.8) \\
24(57.1)\end{array}$ & $\begin{array}{c}179(41.4) \\
13(31.0)\end{array}$ & $\begin{array}{c}94(21.8) \\
5(11.9)\end{array}$ & 6.919 & 0.031 \\
\hline $\begin{array}{l}\text { Current accommodation } \\
\text { College residency } \\
\text { Family home } \\
\text { Rented apartment } \\
\text { Rented house } \\
\end{array}$ & $\begin{array}{l}117(43.5) \\
30(40.0) \\
20(30.3) \\
16(25.0)\end{array}$ & $\begin{array}{l}125(46.5) \\
27(36.0) \\
25(37.9) \\
15(23.4)\end{array}$ & $\begin{array}{l}27(10.0) \\
18(24.0) \\
31(31.8) \\
33(51.6)\end{array}$ & 61.522 & $<0.001$ \\
\hline $\begin{array}{l}\text { Current staying with } \\
\text { Alone } \\
\text { Family/relative } \\
\text { Housemates } \\
\text { Roommate }\end{array}$ & $\begin{array}{l}119(43.4) \\
33(45.2) \\
16(30.8) \\
15(20.0)\end{array}$ & $\begin{array}{l}120(43.8) \\
24(32.9) \\
23(44.2) \\
25(33.3)\end{array}$ & $\begin{array}{l}35(12.8) \\
16(21.9) \\
13(25.0) \\
35(46.7)\end{array}$ & 45.698 & $<0.001$ \\
\hline
\end{tabular}


experiencing psychological problems. Even though at the beginning some of these students were well supported, the situation became worse when the outbreak started to become lengthy.

In this study, most students reported unclear learning tasks in the current academic year or semester due to COVID-19 and $24.05 \%$ (more than one-fourth) reported a frequently raised heartbeat. Results from the univariate analysis indicate that female students are more affected than male students by anxiety and stress. However, it is interesting to note that $65.61 \%$ of students reported their anxiety regarding internship and career-related issues during COVID-19, which indicates that students are anxious more about their studies and career rather than their health. This is consistent with Ahmed et al. ${ }^{16}$ in the sense that knowledge can recover from any disruption such as a pandemic. On the other hand, mental disengagement seems crucial in the analysis. Students from business and management majors have more anxiety, contradicting previous studies claiming that music students are more anxious. Those staying in rented apartments were prone to more severe anxiety than those staying at home, which indicates that students may feel psychologically worse if they are without family. This is consistent with the results of the overall study of anxiety levels presented in Table 1. Results from the univariate analysis in Table 2 showed a significant result. The descriptive statistics of coping strategies are shown in Table 1 and 2, and anxiety levels and coping strategies in Table 3. Overall, the socio-psychological impacts for university students in Bangladesh are diverse and complicated: financing and income for survival seem to have more priority than healthcare. The study has number of limitations and implications, which are discussed in the next section.

Table 3. Results from stepwise ordinal multivariate analysis.

\begin{tabular}{|c|c|c|c|c|}
\hline Variable & B & SE & p & $\mathrm{OR}_{\mathrm{adj}}(95 \% \mathrm{CI})$ \\
\hline $\begin{array}{l}\text { Gender } \\
\quad \text { Female } \\
\quad \text { Male }\end{array}$ & $\begin{array}{c}0.481 \\
\text { ref }\end{array}$ & 0.213 & 0.024 & $\begin{array}{c}1.618(1.064,2.460) \\
1\end{array}$ \\
\hline $\begin{array}{l}\text { Age } \\
\qquad \begin{array}{l}18 \text { and below } \\
19-25 \text { years } \\
26-32 \text { years } \\
33 \text { - } 40 \text { years } \\
\text { Above } 40 \text { years }\end{array}\end{array}$ & $\begin{array}{c}\text { ref } \\
2.326 \\
2.782 \\
2.120 \\
3.192\end{array}$ & $\begin{array}{l}0.451 \\
0.335 \\
0.572 \\
0.742\end{array}$ & $\begin{array}{l}<0.001 \\
<0.001 \\
<0.001 \\
<0.001\end{array}$ & $\begin{array}{c}1 \\
10.235(4.226,24.787) \\
16.146(8.365,1.165) \\
8.330(2.711,25.596) \\
24.326(5.673,104.314) \\
\end{array}$ \\
\hline $\begin{array}{l}\text { Nationality } \\
\text { Bangladeshi } \\
\text { Chinese } \\
\text { Pakistani }\end{array}$ & $\begin{array}{c}\text { ref } \\
0.789 \\
-1.012\end{array}$ & $\begin{array}{l}0.225 \\
0.696\end{array}$ & $\begin{array}{c}<0.001 \\
0.146\end{array}$ & $\begin{array}{c}1 \\
2.200(1.413,3.426) \\
.363(0.093,1.422)\end{array}$ \\
\hline $\begin{array}{l}\text { College } \\
\text { Business/Management } \\
\text { Engineering } \\
\text { Social Science/Humanities } \\
\text { Others }\end{array}$ & $\begin{array}{l}1.089 \\
0.917 \\
0.838 \\
\text { ref }\end{array}$ & $\begin{array}{l}0.413 \\
0.420 \\
0.421\end{array}$ & $\begin{array}{l}0.008 \\
0.029 \\
0.047\end{array}$ & $\begin{array}{l}2.971(1.321,6.685) \\
2.502(1.098,5.704) \\
2.312(1.012,5.279) \\
1\end{array}$ \\
\hline $\begin{array}{l}\text { Level of study } \\
\text { Undergraduate } \\
\text { Masters } \\
\text { Phd }\end{array}$ & $\begin{array}{c}2.872 \\
0.929 \\
\text { ref }\end{array}$ & $\begin{array}{l}0.518 \\
0.460\end{array}$ & $\begin{array}{l}<0.001 \\
0.043\end{array}$ & $\begin{array}{c}17.671(6.392,48.855) \\
2.532(1.028,6.238) \\
1\end{array}$ \\
\hline $\begin{array}{l}\text { Year of study } \\
\text { Year } 1 \\
\text { Year } 2 \\
\text { Year } 3 \\
\text { Year } 4 \\
\text { Year } 5 \text { and above }\end{array}$ & $\begin{array}{c}0.764 \\
2.317 \\
3.079 \\
1.091 \\
\text { ref }\end{array}$ & $\begin{array}{l}0.612 \\
0.655 \\
0.679 \\
0.695\end{array}$ & $\begin{array}{l}0.212 \\
<0.001 \\
<0.001 \\
0.117\end{array}$ & $\begin{array}{c}2.146(0.646,7.125) \\
10.148((2.811,36.632) \\
21.741(5.738,82.371) \\
2.976(.762,11.631) \\
1\end{array}$ \\
\hline $\begin{array}{l}\text { Virtual learning } \\
\text { Yes } \\
\text { No }\end{array}$ & $\begin{array}{c}1.328 \\
\text { ref }\end{array}$ & 0.372 & $<0.001$ & $\begin{array}{c}3.774(1.808,7.874) \\
1\end{array}$ \\
\hline $\begin{array}{l}\text { Current accommodation } \\
\text { College residency } \\
\text { Family Home } \\
\text { Rented apartment } \\
\text { Rented house }\end{array}$ & $\begin{array}{c}-0.467 \\
-0.682 \\
-0.100 \\
\text { ref }\end{array}$ & $\begin{array}{l}0.463 \\
0.527 \\
0.471\end{array}$ & $\begin{array}{l}0.313 \\
0.196 \\
0.832\end{array}$ & $\begin{array}{l}.627(.253,1.555) \\
.505(.180,1.422) \\
.905(.359,2.279) \\
1\end{array}$ \\
\hline $\begin{array}{l}\text { Current staying with } \\
\text { Alone } \\
\text { Family/relative } \\
\text { Housemates } \\
\text { Roommate }\end{array}$ & $\begin{array}{c}0.225 \\
-0.177 \\
-0.911 \\
\text { ref }\end{array}$ & $\begin{array}{l}0.438 \\
0.530 \\
0.478\end{array}$ & $\begin{array}{l}0.608 \\
0.742 \\
0.057\end{array}$ & $\begin{array}{c}1.252(.530,2.955) \\
.838(.291,2.408) \\
.402(.157,1.026) \\
1\end{array}$ \\
\hline
\end{tabular}

$\mathrm{B}$, regression coefficient; $\mathrm{SE}$, standard error; $\mathrm{OR}$, odds ratio; $\mathrm{Cl}$, confidence interval. 


\section{Limitations, conclusion and future research}

Our study has a few limitations. First, the study is limited to students from different universities in Bangladesh and different subject areas. Also, the respondents were randomly selected due to online data collection from various cities within a short period of time due to the urgency of the research topic. The respondents are Bangladeshi students, mainly from various recognized universities in Dhaka. Thus, it should not be generalized to the overall student group. Future studies should investigate a proportional study among school, college and university students, ${ }^{21}$ focus on COVID19-infected areas where students are severely affected, or conduct a comparative analysis among red, yellow and green zones as defined by the local government recently. In addition, the most and least affected areas should be separately investigated to understand the phenomenon in depth. In the future, a mixed methodology approach using qualitative and quantitative techniques may further deepen the investigation within a bibliometric context. This research is based on empirical analysis, which may affect the generalizability of the research. A more in-depth technique such as interviews or other qualitative measures in the future may deepen students' coping strategies. Furthermore, if the university authority, administrative staff and teachers could be selected as respondents, the study might have more interesting findings.

Despite the limitations, the study has numerous implications for society. First, the university authority should be aware of students' coping strategies. ${ }^{23}$ Students who live without parents or relatives should be taken care of particularly seriously during the outbreak. Second, to cope with mental pressure, ${ }^{24}$ university authority may think about arranging programs such as experience-sharing competitions and encourage students to take part by offering rewards or financial aid. Finally, required food and healthcare stuffs should be supplied to ensure students' safety.

Pandemics such as COVID-19 can badly affect academic activities and interrupt routine activities. To lessen this problem, the study sheds light on the socio-psychological strategies of Bangladeshi students during the COVID-19 pandemic. Due to the lockdown policy, many students have had to stay in university accommodation without being allowed to go out. The psychological effects have been as crucial for students in Bangladesh as in any pandemic. The overall findings of the study clearly indicate a significant relationship between university students and their socio-psychological issues such as anxiety during the COVID-19 in Bangladesh. Increasing psychological pressure on students is consistent with our study findings: $45.56 \%$ of respondents reported headaches and neck pains, indicating psychological manifested in a physical disturbance. Socio-psychological issues affect regular academic activities such as class attendance and assignments. As a result, coping strategies for avoiding socio-psychological issues should be identified for students in case they face any future epidemic challenges, ${ }^{25}$ which may help to ensure a seamless educational experience in society.
Correspondence: Syed Far Abid Hossain, College of Business Administration, International University of Business Agriculture and Technology (IUBAT), 4 Embankment Drive Road, Sector-10, Uttara Model Town, Dhaka 1230, Bangladesh.

E-mail: sfa_hossain@yahoo.com.

Key words: Socio-psychology; students; university; Bangladesh; COVID-19.

Conflicts of interest: The authors declare no conflict of interest

Contributions: Conceptualization: SH, MN, SS, GB, KC, KK; Methodology: KC; Software and formal analysis: KC; Data curation: $\mathrm{SS}, \mathrm{KC}$; Writing - original draft preparation: $\mathrm{SH}, \mathrm{MN}, \mathrm{KC}, \mathrm{KK}$; Writing - review and editing: SH, MN, SS, HK, AS; Funding acquisition: SS, MN, HK. All authors have read and agreed to the published version of the manuscript.

Funding: This research was funded by PSU COVID-19 Emergency Research Program (grant ID: COVID19-CBA-2020-39).

Received for publication: 25 August 2020.

Accepted for publication: 2 November 2020.

C Copyright: the Author(s), 2021

Licensee PAGEPress, Italy

Journal of Public Health Research 2020; 9(s1):1911

doi:10.4081/jphr.2020.1911

This work is licensed under a Creative Commons Attribution NonCommercial 4.0 License (CC BY-NC 4.0).

\section{References}

1. International Monetary Found. Policy Responses to COVID19. 2020. Available from: https://www.imf.org/en/Topics/imfand-covid19/Policy-Responses-to-COVID-19

2. Our World in Data [Internet]. Bangladesh: Coronavirus Pandemic 2020. Available from: https://ourworldindata.org/ coronavirus/country/bangladesh?country $=\sim$ BGD

3. European CDC. COVID-19 situation update worldwide, as of 9 June 2020. Available from: https:/www.ecdc.europa.eu/ en/geographical-distribution-2019-ncov-cases

4. Bangladesh Bureau of Statistics. Bangladesh Bureau of Statistics Slum Census and Floating population 2014. 2015. Available

from: http://203.112.218.65:8008/WebTestApplication/userfiles/Ima ge/Slum/FloatingPopulation2014.pdf

5. Mamun MA, Griffiths MD. First COVID-19 suicide case in Bangladesh due to fear of COVID-19 and xenophobia: Possible suicide prevention strategies. Asian J Psychiatry 2020;51:102073

6. Ahorsu DK, Lin C-Y, Imani V, et al. The fear of COVID-19 scale: Development and initial validation. Int J Ment Health Addict 2020. doi: 10.1007/s11469-020-00270-8

7. Sakib N, Bhuiyan AKMI, Hossain S, et al. Psychometric validation of the Bangla fear of COVID-19 scale: Confirmatory factor analysis and rasch analysis. Int J Ment Health Addict 
2020. doi: 10.1007/s11469-020-00289-x

8. Anwar S, Nasrullah M, Hosen MJ. COVID-19 and Bangladesh: Challenges and how to address them. Front Public Health 2020;8:154.

9. WSWS.org [Internet]. Bangladesh Government downplays COVID-19 threat as job losses mount. 2020. Accessed: 2020 Jun 6. Available from: https://www.wsws.org/en/articles/ 2020/03/16/bang-m16.html

10. BBC News [Internet]. Coronavirus: Bangladesh locks down a million in Rohingya camps. 2020. Available from: https://www.bbc.com/news/world-asia-52227924

11. Hossain SFA, Shan X, Nurunnabi M. Is M-learning a challenge? Students attitudes toward the sustainable learning and performance. Int J e-Collab 2019;15:21-37.

12. Hossain MA, Rahman S, Karim MR. The Mental health of school-going children during existing lockdown situation due to COVID-19 pandemic in Bangladesh. Med Pharmacol 2020Available

from: https://www.preprints.org/manuscript/202005.0346/v1

13. Hossain MS, Ferdous S, Siddiqee MH. Mass panic during Covid-19 outbreak- A perspective from Bangladesh as a highrisk country. J Biomed Anal 2020;3:1-3.

14. Van D, McLaws ML, Crimmins J, et al. University life and pandemic influenza: Attitudes and intended behaviour of staff and students towards pandemic (H1N1) 2009. BMC Public Health 2010;10:130.

15. Lau SKP, Woo PCY, Li KSM, et al. Severe acute respiratory syndrome coronavirus-like virus in Chinese horseshoe bats. Proc Natl Acad Sci USA 2005;102:14040-5.

16. Ahmed N, Jahangir Rony R, Tuz Zaman K. Social distancing challenges for marginal communities during COVID-19 pandemic in Bangladesh. J Biomed Anal 2020;3:5-14.

17. Amin S, Rob U, Billah M, et al. COVID-19-related knowl- edge, attitudes, and practices among adolescent girls in Bangladesh. Harvard Dataverse 2020. Available from: https://dataverse.harvard.edu/citation?persistentId=doi:10.791 0/DVN/UBZXWD

18. Cao W, Fang Z, Hou G, et al. The psychological impact of the COVID-19 epidemic on college students in China. Psychiatry Research 2020;287:112934.

19. Wang C, Cheng Z, Yue X-G, McAleer M. Risk Management of COVID-19 by universities in China. J Risk Financial Manag 2020;13:36.

20. Zung WWK. A rating instrument for anxiety disorders. Psychosomatics 1971;12:371-9.

21. Hossain SF, Xi Z, Nurunnabi M, Anwar B. Sustainable academic performance in higher education: a mixed method approach. Interactive Learning Environments 2019:1-4.

22. Roy D, Tripathy S, Kar SK, et al. Study of knowledge, attitude, anxiety \& perceived mental healthcare need in Indian population during COVID-19 pandemic. Asian J Psychiatry 2020;51:102083.

23. Abebe TB, Bhagavathula AS, Tefera YG, et al. Healthcare professionals' awareness, knowledge, attitudes, perceptions and beliefs about Ebola at Gondar University Hospital, Northwest Ethiopia: a cross-sectional study. J Public Health Afr 2016;7:570.

24. Qiu J, Shen B, Zhao M, et al. A nationwide survey of psychological distress among Chinese people in the COVID-19 epidemic: implications and policy recommendations. General Psychiatry 2020;33:e100213.

25. Banerjee D. The COVID-19 outbreak: Crucial role the psychiatrists can play. Asian J Psychiatry 2020;50:102014. 